\title{
Does it exist pulmonary hypertension in the ELBW infants?
}

\author{
Carlo Dani \\ From XXI Congress of the Italian Society of Neonatology \\ Palermo, Italy. 24-26 September 2015
}

Pulmonary hypertension $(\mathrm{PH})$ of the newborn is a severe complication that occurs more frequently in term infants but can be demonstrated also in preterm infants. The incidence of $\mathrm{PH}$ in preterm infants is currently unknown because it is often masked by the contemporary respiratory distress syndrome (RDS), there are not important echocardiography studies in the early transitional period assessingthe presence of $\mathrm{PH}$ in this population, and its echocardiographic diagnosis is not always simple. Similarly to term infants, PHin preterm infants can result from an abnormal transition from fetal to neonatal life (persistence of fetal circulation) but more frequently complicates RDS, or is secondary to the abnormal lung growthcaused by maternal pregnancy diseases, such as preterm premature rupture ofmembranes (PPROM) and oligohydramnios or, finally, is associated to bronchopulmonary dysplasia (BPD). On the other hand, it has been recently demonstratedthat early $\mathrm{PH}$ occurring in association with severe RDS is a risk factor for late PH and BPD in preterm infants.

The first choice drug for the $\mathrm{PH}$ of the newborn is inhaled nitric oxide (iNO), but its effectiveness in preterm infants is highly debated. American Academy of Pediatrics in 2014 reported that previous studies indicate thatneither rescue nor routine use of iNO improves survival in preterm infants with respiratory failure. However, preterm infants with echocardiographic diagnosis of $\mathrm{PH}$ have not been specifically evaluated in previous studies and it is possible that theyrepresent a subgroup witha different response. Interestingly, milrinone has been recently found to be effective in improving oxygenation of preterm infants with $\mathrm{PH}$ refractory to iNO.

In conclusion, it seems that $\mathrm{PH}$ actually exists in extremely low birth weight infants, and that many

Correspondence: cdani@unifi.it

Department of Neuroscience, Psychology, Drug Research and Child Health, Careggi University Hospital of Florence, Italy efforts are needed to improve their finding and their treatment.

Published: 24 September 2015

\section{References}

1. Mirza H, Ziegler J, Ford S, Padbury J, Tucker R, Laptook A: Pulmonary hypertension in preterm infants: prevalence and association with bronchopulmonary dysplasia. J Pediatr 2014, 165:909-14.

2. Kumar VH, Hutchison AA, Lakshminrusimha S, Morin III FC, Wynn RJ, Ryan RM: Characteristics of pulmonary hypertension in preterm neonates. J Perinatol 2007, 27:214-219.

3. American Academy of Pediaatrics: Use of Inhaled Nitric Oxide in Preterm Infants. Pediatrics 2014, 133:164-170.

doi:10.1186/1824-7288-41-S1-A6

Cite this article as: Dani: Does it exist pulmonary hypertension in the ELBW infants? Italian Journal of Pediatrics 2015 41(Suppl 1):A6.
Submit your next manuscript to BioMed Central and take full advantage of:

- Convenient online submission

- Thorough peer review

- No space constraints or color figure charges

- Immediate publication on acceptance

- Inclusion in PubMed, CAS, Scopus and Google Scholar

- Research which is freely available for redistribution
() Biomed Central 